\title{
Technologische hulpmiddelen bij toezicht op delinquenten in de samenleving
}

\author{
Katy de Kogel*
}

Toezicht in de samenleving op volwassen delinquenten kan plaatsvinden binnen verschillende juridische modaliteiten (Boone e.a. 2016). Eén belangrijke categorie is toezicht in het kader van voorwaardelijke invrijheidstelling bij een gevangenisstraf of maatregel (bijvoorbeeld tbs). Een andere belangrijke categorie is toezicht opgelegd als onderdeel van een voorwaardelijke straf of maatregel. De reclassering is verantwoordelijk voor het toezicht. Het toezicht wordt veelal ook uitgevoerd door de reclassering, maar er kunnen ook andere instanties bij betrokken zijn, zoals forensisch psychiatrische (poli)klinieken.

Het toezicht kan verschillende inhoudelijke componenten omvatten. Een veelgemaakt onderscheid daarbij is dat tussen elementen van monitoring en control enerzijds en begeleiding, rehabilitatie en zorg/ behandeling anderzijds (De Kogel \& Nagtegaal 2008). Toezichtprogramma's voor volwassen delinquenten kunnen aanzienlijk verschillen wat betreft de combinatie van verschillende toezichtelementen. Er is enig bewijs voor de effectiviteit in termen van recidivevermindering van toezichtprogramma's die naast controle-elementen, zoals het monitoren van gedrag en bewegingen, óók bestaan uit rehabilitatieve componenten, zoals praktische begeleiding, zorg en vaardigheidstrainingen (De Kogel \& Nagtegaal 2008). Voor vermindering van recidive door pure supervisie is niet of nauwelijks bewijs, maar voor recidivereductie door de combinatie van supervisie en rehabilitatie wel (o.a. Lipsey \& Cullen 2007).

* Dr. C.H. de Kogel is senior wetenschappelijk medewerker bij het Wetenschappelijk Onderzoek- en Documentatiecentrum (WODC) van het ministerie van Justitie en Veiligheid en senior onderzoeker bij de Capaciteitsgroep Strafrecht en Criminologie van de Faculteit Rechten van de Universiteit Maastricht. Voor deze bijdrage is ten dele gebruikgemaakt van het in 2018 verschenen rapport van L.J.M. Cornet, N. Mandersloot, R. Pool \& C.H. de Kogel. De 'zelfmetende' justitiabele. Een verkennend onderzoek naar technologische zelfmeetmethoden binnen de justitiële context. (Den Haag: WODC 2018) 
Hoe kunnen technologische hulpmiddelen bijdragen aan de supervisie- en rehabilitatiefuncties van het toezicht op delinquenten in de maatschappij? Globaal worden technologische hulpmiddelen bij toezicht wel uitgesplitst in zogeheten 'eerste generatie' (gps-tracking) en 'tweede generatie' (smartphone- en sensortechnologie) hulpmiddelen (Pattavina 2009; Corbett \& Pattavina 2015). Hierna wordt besproken wat globaal bekend is over de effectiviteit en veronderstelde werkingsmechanismen van de eerste generatie technische hulpmiddelen. Vervolgens wordt verkend welke meerwaarde de tweede generatie technische hulpmiddelen kunnen hebben en op welke mechanismen ze zouden kunnen aansluiten. Welke nieuwe ontwikkelingen zijn er en wat zijn mogelijke belovende perspectieven daarbij voor de praktijk? Met welke aandachtspunten moeten we rekening houden?

\section{Eerste generatie technische hulpmiddelen bij toezicht}

\section{Elektronisch monitoren}

De eerste generatie hulpmiddelen wordt gebruikt voor het elektronisch monitoren van locatie en bewegingen van onder reclasseringstoezicht gestelde delinquenten. De reclasseringswerker kan op die manier nagaan of betrokkene zich aan de door de rechter opgelegde voorwaarden houdt. Bijvoorbeeld of hij naar opleiding of werk gaat, zich houdt aan een huisarrest, of wegblijft van verboden locaties. Met elektronisch monitoren kan dit op een frequentere en structurelere basis dan met bijvoorbeeld huisbezoeken.

De meest bekende toepassing is een enkelband (pols- of armband) die bevestigd wordt bij de delinquent en waarmee via gps de verplaatsingen en locatie op afstand kunnen worden bepaald (zie voor overzichten apparatuur DeMichele \& Payne 2009; Renzema 2013). Oudere toepassingen zijn apparaten bestaand uit een zender aan de pols van betrokkene en een ontvanger in zijn huis die met behulp van radiofrequentie 'continuous signalling' vaststellen of betrokkene zich al dan niet op de thuisbasis bevindt (om huisarrest te monitoren). De eerst gebruikte vormen van elektronisch monitoren in de jaren tachtig in de Verenigde Staten betroffen geprogrammeerde contactsystemen, 'random calling', met stemverificatie of videoverificatie), die automatisch periodiek telefonisch contact met de delinquent opnemen om te 
checken of hij op de juiste tijd op een bepaalde locatie is. Veel landen investeren in toenemende mate in elektronisch monitoren, dat beschouwd wordt als een kosteneffectief alternatief voor gevangenisstraf en om recidive te verminderen (Belur e.a. 2017).

In 2017 werden door de drie Nederlandse reclasseringsorganisaties bij verdachten en veroordeelden in totaal zo'n 2.850 enkelbandaansluitingen aangelegd, dagelijks dragen ruim 700 mensen een elektronische enkelband. ${ }^{1}$

\section{Veronderstelde mechanismen elektronisch monitoren}

Elektronisch monitoren wordt veelal gezien als een punitief middel met hoofdzakelijk supervisie-elementen, maar het omvat ook elementen van rehabilitatie (overzichten in Renzema 2013; Belur e.a. 2017). Veronderstelde werkzame mechanismen zijn ten eerste afschrikking doordat betrokkene weet dat het gedetecteerd wordt als hij zich niet aan de voorwaarden houdt. Ten tweede zou de moeilijk te verwijderen enkelband het onopgemerkt recidiveren aanzienlijk bemoeilijken. Ten derde is de veronderstelling dat door relatief vroege detectie van het zich niet aan de voorwaarden houden de kans groter wordt dat tijdig kan worden ingegrepen, waardoor ernstiger afglijden en delicten voorkomen kunnen worden. Eerste generatie elektronisch monitoren omvat ook rehabilitatieve elementen. Zo is ten eerste de veronderstelling dat door het door elektronisch monitoren kunnen deelnemen aan een werk-, sociaal en gezinsleven, in plaats van opsluiting, de re-integratie in de maatschappij beter zal verlopen, met een lagere recidivekans tot gevolg. Ten tweede zou de enkelband kunnen helpen een normale dagstructuur te bevorderen bij reclassanten. Ten derde zou de enkelband kunnen beschermen tegen verleidingen en druk van anderen om delicten te plegen, omdat betrokkene bepaalde risicogebieden moet vermijden en minder tijd in de gevangenisomgeving doorbrengt. Ten vierde zou elektronisch monitoren kunnen bijdragen aan een betere rehabilitatie omdat het onderdeel kan zijn van een re-integratieprogramma waar ook therapie deel van uitmaakt. Door toepassing van de enkelband in plaats van gevangenisstraf kan betrokkene toegang krijgen tot therapeutische programma's in de maatschappij,

1 Zie www.reclassering.nl/over-de-reclassering/cijfers-en-feiten. Laatst bezocht 12 april 2019. 
waarbij supervisie met behulp van de enkelband tevens zou kunnen bevorderen dat betrokkene de sessies bezoekt.

\section{Effectiviteit van elektronisch monitoren}

Wat is bekend over de effectiviteit van de eerste generatie technologische hulpmiddelen in toezicht? De eerste systematische review op dit gebied vond nog slechts weinig (quasi-)experimentele studies, een drietal (Renzema \& Mayo-Wilson 2005). De conclusie was dat elektronisch monitoren geen effect had op recidive van hoog- en matig-risicodelinquenten een tot drie jaar later. Een recente systematische review en meta-analyse vond zeventien studies met een (quasi-)experimentele opzet of een tijdseriedesign (Belur e.a. 2017). Over het geheel genomen werd geen statistisch significante vermindering van latere recidive gevonden in groepen die elektronisch monitoren kregen, vergeleken met controlegroepen, die veelal 'gewoon' reclasseringstoezicht, gevangenisstraf of een werkstraf kregen. De effecten van elektronisch monitoren lijken echter genuanceerder en afhankelijk van de context en van kenmerken van de delinquent. Zo werd wel een significante recidivevermindering gevonden bij de groepen die elektronisch monitoren als alternatieve straf kregen, vergeleken met controlegroepen die gevangenisstraf kregen opgelegd (drie studies). Ook leidde elektronisch monitoren bij zedendelinquenten wel tot een significante vermindering van recidive (drie studies). Er werd ook enig bewijs gevonden dat elektronisch monitoren beter werkt als het wordt gecombineerd met interventies zoals therapie of counseling. Dit zou mogelijk ook de uitkomst bij zedendelinquenten kunnen verklaren omdat zij relatief vaak ook therapie krijgen. Een recente quasi-experimentele studie waarin een groot databestand van 16.475 cases werd gebruikt, richtte zich specifiek op de effectiviteit van elektronisch monitoren als alternatieve straf in vergelijking tot een gevangenisstraf (Williams \& Wheatherburn 2019). Gevonden werd een recidivereductie in de elektronisch monitoren-groep van 16 procentpunt ten opzichte van de gevangenisgroep. Voor de jongere groep delinquenten, onder de 30 jaar, was dit 43 procentpunt. De auteurs becijferen dat dit de overheid een kostenbesparing van \$ 30.000 kan opleveren voor elke delinquent die elektronisch monitoren krijgt in plaats van gevangenisstraf. 


\section{Tweede generatie technische hulpmiddelen}

\section{Aanvullende waarde smartphone- en sensortechnologie}

Tweede generatie elektronisch monitoren omvat smartphone- en sensortechnologie veelal in combinatie met gps-tracking. Wat is de aanvullende waarde daarvan? De traditionele enkelband wordt vooral gebruikt als supervisie-element: betrokkene in de gaten houden en betrappen als het misgaat, maar niet als een instrument ten behoeve van gedragsverandering en rehabilitatie (Corbett \& Pattavina 2015). Juist de tweede generatie technologische hulpmiddelen in het toezicht biedt in potentie opties om elektronisch monitoren niet alleen als supervisie-instrument in te zetten, maar ook voor rehabilitatie. Dat komt omdat de toevoeging van smartphone- en sensortechnologie nieuwe mogelijkheden geeft voor communicatie, om feedback te geven en om individuele factoren te meten. Daarmee kan een rijker palet ontstaan aan potentiële mogelijkheden voor de combinatie van supervisie met begeleiding en behandeling.

\section{Coaching in dagelijks leven}

Mobiele communicatieapps kunnen worden benut in de begeleiding en coaching direct betrokken op het dagelijks leven van reclassanten, om hen te helpen zich aan opgelegde voorwaarden te houden. Dit betreft bijvoorbeeld het herinneren aan afspraken of werktijden, of contact leggen op momenten van de dag dat betrokkene kwetsbaar is voor terugval in middelengebruik. Betere begeleiding zou het schenden van voorwaarden kunnen helpen voorkomen (Corbett \& Pattavina 2015). Corbett en Pattavina beargumenteren dat dit hard nodig is, omdat veel reclassanten moeite hebben om hun leven te organiseren, zij kampen als groep met omstandigheden die het moeilijker maken voor hen om zich aan opgelegde voorwaarden te houden. Dit betreft onder meer psychiatrische problematiek, verslaving, gebrekkige opleiding, een verstandelijke beperking, werkloosheid en relatieve armoede.

Een voorbeeld is de Outreach Smartphone Monitoring-app (OSM). ${ }^{2}$ OSM is ontwikkeld in de Verenigde Staten voor justitiabelen onder 
toezicht van de reclassering. Het idee erachter is om toezicht moderner en positiever te maken en de bereidheid van justitiabelen om zich te houden aan de voorwaarden te vergroten. De app bevat naast supervisie-elementen, zoals gps-monitoring, een Alcoholmeter door middel van een blaasfunctie, een alarmeringssysteem bij schending van de voorwaarden, een videoverificatie-optie (o.a. om te zien of degene die blaast ook daadwerkelijk de juiste reclassant is), maar ook ondersteuningselementen zoals een herinneringsoptie (bijvoorbeeld aan afspraken met de reclasseringsmedewerker) en een positief bekrachtigingssysteem. De app heeft verschillende prijzen gewonnen, maar over de effectiviteit ervan is voor zover bekend nog geen informatie.

Ook in Nederland zijn er ontwikkelingen op dit gebied. Sinds mei 2018 kunnen reclassanten via smartphone, tablet of computer bij het 'Cliëntportaal', een 3RO-breed platform. Hier kunnen reclassanten toegang krijgen tot voor hen relevante informatie. Zo kunnen zij bijvoorbeeld afspraken met hun toezichthouder inzien, kunnen ze checken hoeveel uren van hun werkstraf nog openstaan en hebben zij de mogelijkheid informatie met hun toezichthouder te delen. Denk daarbij aan het toevoegen van een nieuw woon- of verblijfadres, het uploaden van documenten of het stellen van doelen binnen hun toezicht. Op deze manier beoogt de reclassering te werken aan het verbeteren van de dienstverlening richting de cliënt, het vergroten van de eigen verantwoordelijkheid en het cliëntvertrouwen. Daarnaast zitten in het Cliëntportaal vier apps van de reclassering verwerkt: 'Stap-voorStap', 'Mijn Risico's', 'Mijn leven' en 'Mijn contacten'. De apps zijn bedoeld om bij te dragen aan de methodische invulling van meldplichtgesprekken. 'Stap-voor-Stap' is een app afgeleid van de Stapvoor-Stap-training, waarbinnen een reclassant aan het denken wordt gezet over zijn middelenmisbruik. 'Mijn Risico's' is een app die het risicoprofiel van een reclassant visualiseert en waarbinnen samen met een reclasseringsmedewerker een delictpreventieplan kan worden opgesteld. Met deze app heeft de reclassant dus altijd zijn persoonlijke delictpreventieplan op zak. Naar schatting maken tussen de 3.000 en 3.500 cliënten gebruik van het Cliëntportaal of hebben een keer ingelogd op het Cliëntportaal (persoonlijke communicatie Stichting Verslavingsreclassering GGZ, 14 augustus 2017; 3RO 2018). 


\section{Stimuleren positief gedrag door bekrachtiging}

Mobiele apps kunnen worden ingezet om positief gedrag en motivatie te stimuleren door middel van bekrachtiging, bijvoorbeeld op momenten dat betrokkene volhoudt, of een goed initiatief neemt. Dit is een belangrijk onderwerp bij justitiabelen bij wie motivatie voor gedragsverandering vaak ontbreekt. De kracht van mobile apps zit hem er dan in dat real-time bekrachtiging gegeven kan worden, direct volgend op het gewenste gedrag, wat cruciaal zou zijn voor succes (Pattavina e.a. 2010). Dit in tegenstelling tot bekrachtiging die in tussentijdse meetings met een reclasseringswerker wordt gegeven en dan noodzakelijkerwijs losgekoppeld is van het moment waarop het gedrag waar het om gaat, werd uitgevoerd. Corbett en Pattavina (2015) betogen dat in het gezondheidsveld en onderwijsveld empirische ondersteuning, blijkend uit systematische reviews, wordt gevonden voor zogeheten 'persuasive technologies', communicatietechnologie die wordt gebruikt om houding en motivatie te verbeteren en op die manier gedrag positief bij te sturen (Hamari e.a. 2014), en voor de effectiviteit van positieve gedragsbekrachtigingsstrategieën bij jongeren met leer- en gedragsproblemen (Allen e.a. 2005). De smartphonetechnologie biedt ook extra mogelijkheden om een sociaal netwerk te betrekken bij het toezicht om betrokkene te steunen en te motiveren. Een voorbeeld is de MyNeON-app, die is ontwikkeld in de Verenigde Staten voor reclassanten en reclasseringsmedewerkers. In deze app staat positieve bekrachtiging voorop. ${ }^{3}$ De app sluit aan bij het NeONproject, waarin reclassanten gestimuleerd worden allerlei activiteiten in hun gemeente te ondernemen, zoals een baan zoeken, scholing volgen of vrijwilligerswerk doen. Wanneer een reclassant een van deze activiteiten wil gaan volgen, kan de app ingezet worden om de juiste locatie en contactgegevens te vinden en krijgt de reclassant punten voor de ondernomen actie. Deze informatie is ook beschikbaar voor de reclasseringsmedewerker, die op die manier de vooruitgang van de reclassant kan volgen. Over de werkzaamheid van de app lijkt nog niets bekend te zijn.

In Nederland is een eerste verkenning van het gebruik van mobiele applicaties in justitiële context verricht door Plaisier en Mol (2016). Zij onderzochten de mogelijkheden van e-begeleiding bij jongeren onder

3 Zie www.russellwebster.com/new-app-provides-comprehensive-support-for-releasedprisoners/. Laatst bezocht 3 juni 2019. 
toezicht van de jeugdreclassering. De jongeren ontvingen binnen dit project sms'jes met daarin opdrachten, herinneringen, psycho-educatie of inspirerende berichten. De resultaten laten zien dat deze vorm van e-begeleiding technisch haalbaar is en dat een deel van de jongeren hiervoor openstaat en het nuttig vindt.

\section{Behandeling in kader van reclasseringstoezicht}

Mobiele apps en sensortechnologie kunnen bijdragen aan behandeling in een justitieel toezichtkader. Vooral voor delinquenten met verslavings- of psychiatrische problematiek zijn er naast de al langer bestaande eHealth-behandelingen (Kip e.a. 2018), zogeheten 'mHealth'-, mobiele, applicaties in opkomst (Ross 2018). De apps zouden een betere personalisering van bejegening en behandeling mogelijk maken en een betere integratie daarvan in het dagelijks leven van betrokkene. Een voorbeeld is de A-CHESS terugvalpreventieapp voor de smartphone, een ondersteunende app na behandeling voor middelenafhankelijkheid (Gustafson e.a. 2011). A-CHESS is getest als component van een US Drug Court-programma (Johnson e.a. 2016).

A-CHESS richt zich op afhankelijkheid van alcohol en drugs en op psychische problemen, en biedt onder andere management van behandelsessies, voortgangsmonitoring, omgaan met symptomen, deelname aan een virtueel ondersteuningsnetwerk, toegang tot een bibliotheek met informatie over behandeling en terugvalpreventiestrategieën op basis van de individuele risicofactoren. Er worden ook apps ontwikkeld gericht op het veranderen van antisociaal probleemgedrag. Een voorbeeld is een app waarbij betrokkene via Facebook dagelijks berichten krijgt van zijn toekomstige zelf, met als doel delinquent gedrag te voorkomen of verminderen (Van Gelder e.a. 2015). Sensortechnologie biedt de mogelijkheid om via wearables (zoals de enkelband, maar ook een polsband of kleding met sensoren) gegevens te verzamelen die in het kader van de combinatie toezicht en behandeling kunnen worden benut. Bijvoorbeeld gegevens over lichaamsbeweging of slaappatronen, maar ook over stress (via sensoren die hartslag en huidweerstand meten) en middelengebruik (een sensor die uit zweet op de huid alcohol en andere drugs kan detecteren). In Nederland is in 2017 een pilot gehouden waarbij reclassanten enkelbanden droegen waaraan een sensor was toegevoegd die het alcoholpercentage meet in zweet (Kruize \& De Muijnck 2018). Deze 
speciale enkelband, de Alcoholmeter, meet 24 uur per dag het alcoholpercentage en de gegevens worden twee keer per dag via een modem aan de reclassering doorgegeven. De proef is een procesevaluatie om uit te wijzen of de Alcoholmeter ingezet kan worden om te controleren of iemand zich aan een alcoholverbod houdt. De 26 reclasseringscliënten die deelnamen en de betrokken reclasseringswerkers waren over het algemeen positief over de bewustwording ten aanzien van het alcoholgebruik en het 'stok achter de deur'-effect dat de Alcoholmeter teweegbracht en dat naar hun mening hielp om niet te drinken. Ook werd de Alcoholmeter door de cliënten geprefereerd boven het zich meermalen per week moeten melden voor urinecontroles. Maar het op twee vaste momenten per dag thuis moeten zijn voor het uitlezen werd als lastig ervaren, evenals de grootte en het draagcomfort van de band. De reclasseringswerkers waarderen de Alcoholmeter vooral als ondersteuningsmiddel voor cliënten die gemotiveerd zijn om hun alcoholgebruik te verminderen. De doelgroep kan wat hen betreft worden uitgebreid, ook buiten het juridisch kader van het alcoholverbod. In de Verenigde Staten en England is er al enige jaren ervaring met de enkelband met alcoholsensor en zijn er gunstige cijfers wat betreft het percentage cliënten dat zich houdt aan het alcoholverbod. ${ }^{4}$

Een nieuwe ontwikkeling is een implanteerbare chip onder de huid in combinatie met een smartphone of smartwatch die alcohol in het lichaam continu kan meten. ${ }^{5}$ De chip is onzichtbaar en je voelt er niets van, en zou daarmee een aantal bezwaren kunnen wegnemen die de Alcoholmeter wel heeft, maar brengt mogelijk wel weer eigen bezwaren mee, zoals inbreuk op de lichamelijke integriteit. 'Implantables' zoals de chip zijn in de context van toezicht echter nog toekomstmuziek en het vergt op dit moment nog veel specialistische kennis om ermee te werken.

Potentieel belangrijk vanuit behandeloogpunt is dat met behulp van smartphone- en sensortechnologie betrokkene ook zelf feedback kan ontvangen over de eigen gegevens. Dit schept nieuwe mogelijkheden voor een actievere rol in de eigen behandeling, die ook binnen het toezicht verder zouden kunnen worden ontwikkeld. Een voorbeeld is een wearable met een hartslag- en of huidweerstandmeter waarbij tevens

4 Zie https://theconversation.com/sobriety-tags-how-alcohol-monitoring-could-become-thenew-norm-98975. Laatst bezocht 12 april 2019.

5 Zie www.smithsonianmag.com/innovation/this-implantable-chip-could-monitor-alcoholintake-180968802/. Laatst bezocht 12 april 2019. 
een biofeedbacksysteem wordt ingebouwd. Deze wordt momenteel in Nederland onderzocht bij adolescenten en jongvolwassenen in ambulante forensische zorg door promovenda Annemieke ten Harmsel (VU afdeling kinder- en jeugdpsychiatrie). Onderwerp van onderzoek is de haalbaarheid en effectiviteit van 'real-time' fysiologische feedback met het oog op het verminderen van problemen die deze jongeren hebben met agressieregulatie. Deze methode zou, indien ze inderdaad effectief blijkt, kunnen worden ingezet in het kader van toezicht ter ondersteuning van het naleven van bepaalde reclasseringsvoorwaarden bijvoorbeeld het niet vertonen van gewelddadig gedrag. Het idee is dat door middel van continue biofeedback cliënten en hun behandelaar of toezichthouder meer inzicht krijgen in het spanningsniveau van de cliënt en dat cliënten bij oplopende spanning een signaal kunnen krijgen dat hen alert maakt om wellicht aangeleerde gedragsvaardigheden (nemen van een time-out bijvoorbeeld) in te zetten om agressieve incidenten te voorkomen.

\section{Dataverzameling voor onder meer voorspellen risico's}

De smartphone- en sensormonitoringtechnologie kunnen worden gebruikt om gegevens te verzamelen die informatie geven over gedragsveranderingen die een signaal kunnen zijn dat risico van het overtreden van voorwaarden of van terugval in verslavings- of psychiatrische problematiek dreigt (Corbett \& Pattavina 2015). Het gaat dan bijvoorbeeld om algoritmen die bewegings- en slaappatronen analyseren in combinatie met activiteit van betrokkene online. Beoogd wordt dat deze mogelijke verslavings- en psychische problemen kunnen helpen signaleren, om zo vroege interventie en preventie mogelijk maken. Tot slot kan de technologie op langere termijn veel gegevens opleveren over welke diensten reclassanten (vooral) gebruiken en over behoeften van bepaalde gemeenten of buurten.

\section{Perspectieven en aandachtspunten}

\section{Kansen}

Technologische hulpmiddelen bieden zeker perspectieven voor het toezicht op delinquenten in de maatschappij. Uit systematische 
reviews blijkt eerste generatie elektronisch monitoren met behulp van de enkelband vooral effectief als dit wordt opgelegd in plaats van gevangenisstraf, en als het wordt opgelegd aan speciale groepen, zoals zedendelinquenten in combinatie met behandeling. Een kanttekening hierbij is wel dat er nog erg weinig studies bestaan die strikte methodologische richtlijnen hebben gevolgd om te zorgen dat de elektronisch monitoren-groep a priori vergelijkbaar is met de controlegroep. In de systematische review van Belur en collega's (2017) hadden slechts twee studies een gerandomiseerd design en de overige vijftien een quasi-experimentele opzet. In het laatste geval is er een iets groter risico dat het gunstige effect van elektronisch monitoren op recidive toe te schrijven zou kunnen zijn aan pre-interventieverschillen tussen de elektronisch monitoren-groep en de controlegroep. Bijvoorbeeld omdat elektronisch monitoren toegewezen wordt aan 'lichtere gevallen' dan gevangenisstraf (zie over dit punt, maar dan bij straf buiten detentie versus gevangenisstraf, ook Villettaz e.a. 2015). Daarnaast richt veel effectonderzoek zich uitsluitend op de uitkomstmaat criminele recidive, terwijl juist ook andere uitkomstmaten bij elektronisch monitoren kansen kunnen bieden om het toezicht effectiever te maken. Bijvoorbeeld het verminderen van risicofactoren, zoals middelengebruik, en het versterken van beschermende factoren, zoals therapietrouw.

Hoe technologische middelen worden ingezet, heeft ook te maken met de tijdgeest. Elektronisch monitoren is vanaf de jaren tachtig in de Verenigde Staten en het Verenigd Koninkrijk vooral als surveillance en controlemiddel ingezet (Renzema \& Mayo-Wilson 2005). De eerste pioniers op het gebied van elektronisch monitoren aan de Harvarduniversiteit in de Verenigde Staten in de jaren zestig hadden de techniek daarentegen juist vooral als hulpmiddel in het kader van rehabilitatie bedoeld (Renzema 2013). De huidige technologische vernieuwingen, smartphone- en sensortechnologie, bieden extra invalshoeken om de supervisie-elementen en de rehabilitatie-elementen te combineren. Toezicht op delinquenten in de maatschappij zou kunnen profiteren van uitbreiding van de enkelband met sensoren (in de toekomst wellicht 'implantables') en van mobiele applicaties voor veelzijdiger toezicht. Zelfredzaamheid en een grotere rol in de eigen behandeling kunnen ook worden gestimuleerd door het personaliseren van behandeling met zelfmeetmethoden, zoals fysiologische metingen of 
het gebruik van mobiele applicaties die de reguliere behandeling ondersteunen en verrijken met feedback.

\section{Uitdagingen}

Ross (2018) noemt drie uitdagingen die aandacht moeten krijgen als mobiele (smartphone) technologie onderdeel van toezicht in de maatschappij moet worden: kwaliteit van applicaties en apparatuur, aanpassing van de toezichtpraktijk en toegankelijkheid voor reclassanten.

\section{Kwaliteit}

Er moet worden gezorgd voor mobiele applicaties van goede kwaliteit (betrouwbaar, valide en veilig) die werkelijk een meerwaarde hebben voor reclasseringswerkers en reclassanten (effectief zijn). Hoewel veelbelovend, ontbreekt bij het overgrote deel van de toepassingen van de tweede generatie smartphone- en sensortechnologie vooralsnog informatie over de effectiviteit. Veel toepassingen zijn erg nieuw en effectonderzoek is vaak nog niet beschikbaar. Een eerste review van forensische $e$-mental health apps is er inmiddels (Kip e.a. 2018). Systematisch evaluatieonderzoek wordt wel bemoeilijkt doordat de technologische ontwikkelingen zo snel gaan. Zo is er een voorbeeld van een review van mental health apps, waarbij bij het verschijnen de techniek waarop de meeste apps gebaseerd waren, tekst messaging, ten tijde van de review al weer achterhaald was (Free e.a. 2013). Een vergelijkbaar voorbeeld is er wat betreft polsbanden met activity trackers: de banden die het best scoorden op betrouwbaarheid en validiteit bleken bij publicatie van de review al niet meer verkrijgbaar (Kooiman e.a. 2015). Het belang van effectonderzoek om het kaf van het koren te scheiden wordt geïllustreerd door ontwikkelingen in de (geestelijke) gezondheidssector, waar mobiele apps al langer gebruikt worden in begeleiding en behandeling dan op justitieterrein. Onderzoek laat zien dat er veel gemakkelijk verkrijgbare apps van slechte kwaliteit in omloop zijn, onder bijvoorbeeld hulpprogramma's voor problematisch middelengebruik (Weaver e.a. 2013). Dit risico zou ook in de forensische sector kunnen gaan spelen als het aantal apps op dat gebied toeneemt. 


\section{Veiligheid}

Niet alleen over de betrouwbaarheid en validiteit van mobiele apps en wearables met sensoren heerst onduidelijkheid, ook over de veiligheid van de apparaten en dataverkeer zelf is nog veel onduidelijk (Cornet e.a. 2018). Want in hoeverre zijn de metingen bijvoorbeeld te manipuleren? Het kan zijn dat de justitiabele of de behandelaar gebaat is bij manipulatie van de gegevens om de werkelijke gegevens bijvoorbeeld mooier te laten lijken dan ze werkelijk zijn. De mogelijkheid om data te manipuleren kan een serieus probleem vormen voor het gebruik van zelfmeetmethoden in de justitiële context. Op welke manier deze manipulatie dan plaats zou kunnen vinden en wat ertegen gedaan zou kunnen worden, behoeft verdere verkenning. Tevens moet rekening worden gehouden met het feit dat anderen dan de gebruiker zelf toegang kunnen krijgen tot de data en deze potentieel kunnen misbruiken. Hackers doen steeds meer moeite om toegang te krijgen tot persoonlijke data van individuen met als doel deze uit te baten. Er zijn door de jaren heen meerdere voorbeelden van wearables die gehackt werden. Zo bleek het mogelijk om met enkele kleine handelingen de Fitbit fitness tracker met malware te besmetten via bluetooth. ${ }^{6}$

Ross (2018) noemt ook het punt dat de toezichtpraktijk zich moet aanpassen om effectief met de nieuwe technologie te kunnen werken. Een goed en veilig georganiseerde ICT-infrastructuur is van groot belang om in het toezicht op delinquenten in de maatschappij gebruik te kunnen maken van mobiele smartphone- en sensortechnologie. Denk in dit verband ook aan het terugdringen van storingsgevoeligheid. Recent (10 mei 2019) trad bijvoorbeeld door een software-update een storing op in het dataverkeer bij elektronisch monitoren, waardoor een groot aantal justitiabelen met enkelband preventief werd ingesloten. ${ }^{7}$ In 2018 werd het dataverkeer met betrekking tot de enkelbanden ook al een keer verstoord door een probleem bij de internetprovider. ${ }^{8}$ Een juridisch aandachtspunt is dat in Nederland strenge regelgeving geldt omtrent de verzameling en verwerking van bijzondere persoonsgegevens. Voor justitie en reclassering gelden iets ruimere voorwaarden voor de verzameling van persoonsgegevens, die zijn bijvoorbeeld

6 Zie www.techopedia.com/hacking-wearable-tech-the-potential-danger-of-advancingwearable-technology/2/33649. Laatst bezocht 5 juni 2019.

7 Zie www.rijksoverheid.nl/actueel/nieuws/2019/05/10/storing-in-elektronische-monitoringenkelbanden.

8 Zie https://nos.nl/artikel/2245297-honderden-elektronische-enkelbanden-uitgevallen-door -telecomstoring.html. 
op de enkelband van toepassing, maar om dit ook te laten gelden voor het gebruik van mobiele smartphoneapps en wearables met sensoren moet de noodzakelijkheid van dit soort methoden aantoonbaar worden gemaakt.

\section{Kennis en begeleiding}

Ook moet worden gezorgd dat de technologie beschikbaar en toegankelijk genoeg is voor reclassanten en is het nodig hen te motiveren om de toepassingen te gebruiken. Ook bij de reclasseringswerkers moet daartoe voldoende kennis van de technologie aanwezig zijn.

Professionals moeten erop bedacht zijn dat niet iedereen de capaciteiten (fysiek, mentaal, emotioneel) heeft om de technologie zonder meer te gebruiken. Vragen die hierbij opkomen, zijn: Wordt volledig begrepen hoe het apparaat gebruikt moet worden? Zijn de voor- en nadelen van het apparaat bekend? Zeker als het gaat om een justitiële doelgroep, bij een deel waarvan het verstandelijk vermogen beperkt is, moeten we ons ervan bewust zijn dat een goede en volledige voorlichting en begeleiding belangrijk zijn.

De applicaties en draagbare sensoren kunnen als indringend worden ervaren, of als (extra) straf in termen van leefstijlbeperking en stigma. Bekend is dat dragers van de enkelband zich gestigmatiseerd kunnen voelen (Post e.a. 2005). Meer dan bij gewoon toezicht kan 24-uurstracking een 'big-brothergevoel' oproepen. Het is zeer waarschijnlijk dat mobiele apps en wearables met sensoren met een tweeledig doel ingezet worden: enerzijds om de justitiabele meer te empoweren vanuit een rehabilitatieoogmerk, anderzijds om meer zicht te krijgen op individuele patronen en op basis van die informatie bijvoorbeeld veiligheidsingrepen te kunnen doen. Dit hoeft niet problematisch te zijn, als er maar heldere communicatie naar de justitiabele toe is over de doelen van de zelfmeetmethode en wie er naast de justitiabele nog meer 'meekijkt' naar de verzamelde informatie.

\section{Tot slot}

In dit artikel is verkend welke meerwaarde zogeheten tweede generatie technische hulpmiddelen (smartphone- en sensortechnologie) zouden kunnen hebben voor toezicht op delinquenten in de maatschappij. Zogenoemde eerste generatie technische hulpmiddelen, 
zoals elektronisch monitoren met behulp van gps, zijn vooral ingezet vanuit supervisieoogpunt. Smartphone- en sensortechnologie kunnen eveneens bijdragen aan de supervisiefunctie, maar hebben ook potentie om juist aan de rehabilitatiefuncties van het toezicht bij te dragen, onder meer omdat ze mogelijkheden bieden tot een meer gepersonaliseerde begeleiding en voor de combinatie van toezicht en behandeling. Hoewel wat dit betreft initiatieven zijn gestart en er onderzoek loopt, is er op dit moment nog nauwelijks iets bekend over de effectiviteit van deze nieuwe technologische toepassingen. Ook vergen de betrouwbaarheid en veiligheid van ICT evenals ethische en juridische aspecten aandacht. Kortom, de toepassingen van nieuwe technologie in het toezicht zijn pril maar hoopvol.

\section{Literatuur}

\section{RO 2018}

3RO, Functioneel ontwerp Cliëntportaal $3 R O$ versie 1.0, Utrecht: 3RO 2018.

\section{Allen e.a. 2005}

D. Allen, W. James, J. Evans, J. Hawkins \& R. Jenkins, 'Positive behavioural support: Definition, current status, and future directions', Tizard Learning Disability Review (10) 2005, afl. 2, p. 4-11.

\section{Belur e.a. 2017}

J. Belur, A. Thornton, L. Tompson, M. Manning, A. Sidebottom \& K, Bowers, A systematic review of the effectiveness of the electronic monitoring of offenders (What Works Crime Reduction Systematic Review Series, no. 13), 2017, https://whatworks.college. police.uk/Research/Systematic_ Review_Series/Documents/ Electronic_monitoring_SR.pdf.

\section{Boone e.a. 2016}

M. Boone, M. van der Kooij \& S. Rap, Current uses of electronic monitoring in the Netherlands, Utrecht: Universiteit Utrecht 2016.

\section{Corbett \& Pattavina 2015}

R.P. Corbett \& A. Pattavina, 'Promoting offender change in the community: Positive reinforcement through EM technology', Journal of Community Corrections 2015 (Summer), p. 5-16.

\section{Cornet e.a. 2018}

L.J.M. Cornet, N. Mandersloot, R. Pool \& C.H. de Kogel, De 'zelfmetende' justitiabele. Een verkennend onderzoek naar technologische zelfmeetmethoden binnen de justitiële context, Den Haag: WODC 2018. 


\section{DeMichele \& Payne 2009}

M. DeMichele \& B.K. Payne, Offender supervision with electronic supervision: A community corrections resource, Washington: Bureau of Justice Assistance, U.S. Department of Justice, Office of Justice Programs 2009.

\section{Free e.a. 2013}

C. Free, G.G. Philips, L.H. Galli, L. Watson e.a., 'The effectiveness of mobile-health technologybased health behaviour change or disease management interventions for health care consumers: A systematic review', PLoS Med 2013, 10e1001362.

\section{Van Gelder e.a. 2015}

J.L. van Gelder, E.C. Luciano, M. Weulen Kranenbarg \& H.E. Hershfield, 'Friends with my future self: Longitudinal vividness intervention reduces delinquency', Criminology (53) 2015, afl. 2, p. 158-179.

\section{Gustafson 2011}

D.H. Gustafson, M.G. Boyle, B.R. Shaw, A. Isham e.a. , 'An e-health solution for people with alcohol problems', Alcohol Research and Health (33) 2011, p. 327-337.

\section{Hamari e.a. 2014}

J. Hamari, J. Koivisto \& T. Pakkanen, 'Do persuasive technologies persuade? A review of empirical studies', in: A. Spagnoli, L. Chittaro \& L. Gamberini (red.), Persuasive technology, Basel: Springer 2014, p. 118-136.

\section{Johnson e.a. 2016}

K. Johnson, S. Richards, M-Y. Chih, T.J. Moon, H. Curtis \& D.H. Gustafson, 'A pilot test of a mobile app for drug court participants', Substance Abuse: Research and Treatment (10) 2016, p. 1-7.

\section{Kip e.a. 2018}

H. Kip, Y.H.A. Bouman, S.M. Kelders \& L.J.E.W.C. van Gemert-Pijnen, 'eHealth in treatment of offenders in forensic mental health: A review of the current state', Frontiers in Psychiatry (42) 2018, afl. 9, p. 1-19.

\section{De Kogel \& Nagtegaal 2008}

C.H. de Kogel \& M.H. Nagtegaal, Toezichtprogramma's voor delinquenten en forensisch psychiatrische patiënten. Effectiviteit en veronderstelde mechanismen (Onderzoek en Beleid 263), Den Haag: WODC/Boom Juridische uitgevers 2008. 


\section{Kooiman e.a. 2015}

T.J.M. Kooiman, M.L. Dontje, S.R. Sprenger, W.P. Krijnen, C.P. van der Schans \& M. de Groot, 'Reliability and validity of ten consumer activity trackers', BMC Sports Science, Medicine \& Rehabilitation 2015, afl. 7, p. 1-11.

\section{Kruize \& De Muijnck 2018}

A. Kruize \& J. de Muijnck, Evaluatie pilot Alcoholmeter 2017, Groningen/Rotterdam: Breuer \& Intraval 2018.

\section{Lipsey \& Cullen 2007}

M.W. Lipsey \& F.T. Cullen, 'The effectiveness of correctional rehabilitation: A review of systematic reviews', Annual Review of Law and Social Sciences 2007, afl. 3, p. 297-320.

\section{Pattavina 2009}

A. Pattavina, 'The use of electronic monitoring as persuasive technology: Reconsidering the empirical evidence on the effectiveness of electronic monitoring', Victims and Offenders 2009, afl. 4, p. 385-390.

\section{Pattavina e.a. 2010}

A. Pattavina, K. Miofsky-Tusinski \& J.M. Byrne, 'Innovation in community corrections: From monitoring technology to persuasive technology', Journal of Offender Monitoring (23) 2010, afl. 1, p. 1-5.

\section{Plaisier \& Mol 2016}

J.W. Plaisier \& M. Mol, 'Innovatie in de sanctietoepassing: gedragsverandering van delinquenten door e-begeleiding', Sancties (54) 2016, afl. 6, p. 321-329.

\section{Post e.a. 2005}

B. Post, L. Tielemans \& C. Woldringh, Geboeid door de enkelband, 2005, www.bvekennis.nl/ Bibliotheek/17-0386.pdf (geraadpleegd op 19 september 2017).

\section{Renzema 2013}

M. Renzema, 'Evaluative research on electronic monitoring', in: M. Nellis, K. Beyens \& D. Kaminski (red.), Electronically monitored punishment: International and critical perspectives, Londen: Routledge 2013, p. 1-18.

\section{Renzema \& Mayo-Wilson 2005}

M. Renzema \& E. Mayo-Wilson, 'Can electronic monitoring reduce crime for moderate to high-risk offenders?', Journal of Experimental Criminology (1) 2005, afl. 2, p. 215-237.

\section{Ross 2018}

S. Ross, 'Policy, practice and regulatory issues in mobile technology treatment for forensic clients', European Journal of Probation (10) 2018, afl. 1, p. 44-58. 


\section{Villettaz e.a. 2015}

P. Villettaz, G. Gillieron \& M. Killias, 'The effects on re-offending of custodial vs. non-custodial sanctions: An updated systematic review of the state of the knowledge', Campbell Systematic Reviews 2015/1.

\section{Weaver e.a. 2013}

E.R. Weaver, D.R. Horyniak, R. Jenkinson, P. Dietze e.a., “"Let's get wasted!" and other apps: Characteristics, acceptability, and use of alcohol-related smartphone applications', JMIR mHealth and eHealth (1) 2013, afl. 1, e9.

\section{Williams \& Wheatherburn 2019}

J. Williams \& D. Wheatherburn, Can electronic monitoring reduce reoffending? (IZA DP no. 12122), Bonn: IZA Institute of Labor Economics 2019. 